\title{
Clinical Data
}

National Cancer Institute

\section{Source}

National Cancer Institute. Clinical Data. NCI Thesaurus. Code C15783.

Data obtained through patient examination or treatment. 